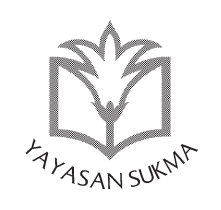

SUKMA: JURNAL PENDIDIKAN

ISSN: 2548-5105 (p), 2597-9590 (e)

Volume 3 Issue 2, Jul-Dec 2019, pp. 217-231

https://doi.org/10.32533/03205.2019

www.jurnalsukma.org

\title{
IDENTIFIKASI SIKAP RASA INGIN TAHU SISWA TERHADAP PEMBELAJARAN FISIKA DI MAN 1 BATANGHARI
}

\section{Irma Fadilah; Kartini}

Universitas Jambi, Indonesia; SMAN 1 Bayung Lencir, Musi Banyuasin, Indonesia

email: irmafadila1234@gmail.com

\section{Abstract}

Pada abad 21 ini dibutuhkan sebuah pendidikan karakter guna membentuk siswa-siswa yang tidak hanya cerdas pengetahuan namun juga cerdas budi pekerti. Terdapat 18 karakter budaya bangsa yang telah dicetuskan pemerintah, salah satu karakter tersebut rasa ingin tahu. Tujuan penelitian ini adalah untuk mengidentifikasi sikap rasa ingin tahu siswa pada pembelajaran fisika di MAN 1 Batanghari. Subjek penelitian adalah 35 siswa kelas X IPA di MAN 1 Batnghari. hasil penelitian ini yaitu terdapat 9 siswa yang 
memperoleh nilai baik dengan persentase $25.7 \%$ dan 26 siswa yang memperoleh nilai sangat baik dengan persentase $74.3 \%$. Hal ini menunjukkan bahwa sikap rasa ingin tahu yang ada pada siswa kelas X IPA di MAN 1 Batanghari tergolong kuat, dibuktikan juga dengan adanya pertanyaan-pertanyaan yang diajukan siswa pada saat observasi.

Keywords: Pendidikan Karakter, Rasa Ingin Tahu, Pembelajaran Fisika

\section{A. Pendahuluan}

Guru merupakan seseorang yang sangat berperan untuk mencerdaskan anak bangsa. Seorang guru pada umumnya adalah seseorang yang bertugas untuk mendidik, membimbing, mengajar, melatih, menilai, mengarahkan dan mengevaluasi peserta didik. Sehingga untuk menjadi seorang guru haruslah memiliki sikap atau karakter yang baik supaya dapat dijadikan sebagai panutan oleh peserta didiknya. Selain menjadi sebagai panutan sesuai tuntutan kurikulum 2013 guru berperan sebagai fasilitator dan motivator.

Seiring berkembangnya zaman, pendidikan di Indonesia kian lama kian membaik diiringi dengan penyediaan sekolah di daerah-daerah 3T (Tertinggal, Terdepan, dan Terluar). Hal ini dilakukan pemerintah karena pendidikan merupakan salah satu indikator sebuah negara dikatakan maju dan berkembang, dengan pendidikan pula yang menjadi sebuah tonggak kebangkitan suatu bangsa (Silmi \& Kusmarni 2017, 230). Untuk itu pemerintah mewajibkan seluruh masyarakat Indonesia untuk menempuh jenjang pendidikan selama 9 tahun. Akan tetapi, saat ini pendidikan di Indonesia siswa-siswanya hanya dituntut untuk menjadi pintar namun tidak diimbangi dengan sikap yang baik, maka diperlukannya peran pendidikan karakter, guna membentuk siswa-siswa yang tidak hanya cerdas pengetahuan namun juga cerdas budi pekerti. 
Pembangunan karakter bangsa diarahkan menjadi bagian yang tidak terpisahkan dari upaya pencapaian visi pembangunan nasional sebagaimana yang tercantum dalam Rencana Pembangunan Jangka Panjang Tahun 2005-2025 (Kebijakan Nasional Pembangunan Karakter Bangsa 2010, 24). Pelaksanaan fungsi dan tujuan pendidikan karakter ini telah diterbitkan dalam Permendiknas No. 23/2006 tentang Standar Kompetensi Lulusan (Kemendiknas 2010,38). Pendidikan karakter merupakan suatu upaya pembentukkan karakter yang dipengaruhi oleh lingkungan. Hal ini selaras dengan pernyataan Samani \& Hariyanto (2013, 43) yang mengungkapkan bahwa karakter sebagai nilai dasar yang membangun pribadi seseorang, terbentuk baik karena pengaruh hereditas maupun pengaruh lingkungan, yang membedakan dengan orang lain, serta diwujudkan dalam sikap dan perilakunya dalam kehidupan sehari-hari (Ramadhani 2014).

Upaya penguatan karakter yang dicetuskan oleh pemerintah diwujudkan dengan pengembangan 18 karakter budaya bangsa. Karakter tersebut adalah "(1) Religius, (2) Jujur, (3) Toleransi, (4) Disiplin, (5) Kerja Keras, (6) Kreatif, (7) Mandiri, (8) Demokratis, (9) Rasa Ingin Tahu, (10) Semangat Kebangsaan, (11) Cinta Tanah Air, (12) Menghargai Prestasi, (13) Bersahabat atau Komunikatif, (14) Cinta Damai, (15) Gemar Membaca, (16) Peduli Lingkungan, (17) Peduli Sosial, (18) Tanggung-jawab (Putri 2011, 9). Delapan belas karakter budaya bangsa tersebut wajib dikembangkan di sekolah (Fauzi et.al. 2017).

Dari delapan belas karakter budaya bangsa tersebut, salah satunya dalah sikap rasa ingin tahu. Rasa ingin tahu menjadi dasar dalam mempelajari sesuatu sehingga mendorong dan menjadi motivasi. Rasa ingin tahu dapat menciptakan motivasi untuk menemukan, mengetahui dan mempelajari suatu materi. Oleh karena itu perlu diciptakan iklim pembelajaran di kelas yang dapat menciptakan dan memelihara rasa ingin tahu siswa. Rasa ingin tahu merupakan salah satu sikap yang dapat dikembangkan dalam pembelajaran fisika (Sari 2016).

Jadi Idealnya, dengan rasa ingin tahu yang tinggi terhadap 
pembelajaran fisika maka akan meningkatkan sikap berfikir kritis dan kreatif pada diri siswa tersebut yang dapat memicu pada peningkatan prestasi hasil belajar siswa. Berdasarkan pemaparan diatas maka peneliti perlu untuk melakukan identifikasi karakter rasa ingin tahu siswa pada pembelajaran fisika di MAN 1 Batanghari guna untuk meningkatkan pengetahuan siswa dalam pembelajaran fisika.

\section{B. Rasa Ingin Tahu}

Menurut Supranoto (2015) rasa ingin tahu adalah sikap dan tindakan yang selalu berupaya untuk mengetahui lebih mendalam dan meluas dari suatu yang dipelajarinya, dilihat, dan didengar. Rasa ingin tahu juga merupakan suatu dorongan yang kuat akan kebutuhan, rasa haus atau hasrat untuk mengetahui, melihat dan adanya motivasi perilaku penelaahan untuk mendapatkan informasi baru yang berasal dari ketidak pastian dalam diri siswa yang menyebabkan konflik konseptual dalam diri siswa. Dalam domain kognitif rasa ingin tahu memiliki manfaat untuk menciptakan berfikir kritis dan kreatif bagi siswa. Sehingga dapat dikatakan pula bahwa rasa ingin tahu merupakan salah satu sikap emosi alamiah yang ada pada diri setiap siswa untuk selalu bertanya dan mencari tahu.

Daryanto dan Darmiatun $(2013,131)$ berpendapat bahwa Indikator rasa ingin tahu adalah (1) Bertanya kepada guru dan teman tentang materi pelajaran, (2) bertanya kepada sesuatu tentang gejala alam yang baru terjadi, (3) bertanya kepada guru tentang sesuatu yang didengar dari radio atau televisi, (4) bertanya tentang berbagai peristiwa yang dibaca dari media cetak. Menurut Rafhy (2014 dalam Oktavioni 2017) indikator sikap ilmiah pada dimensi Sikap ingin tahu memiliki indikator (1) Antusias mencari jawaban, (2) Perhatian pada objek yang diamati, (3) Antusias pada proses sains, (4) Menanyakan setiap langkah-langkah kegiatan.

Berdasarkan beberapa pendapat ahli Oktaviani (2017) kemudian menyimpulkan beberapa indikator rasa ingin tahu dari 
Identifikasi Sikap Rasa Ingin Tahu Siswa terhadap Pembelajaran Fisikadi

beberapa teori dan peneliti menggunakan lima indikator yang dianggap penting dan mudah untuk diamati dari beberapa indikator diatas. Adapun indikator-indikator tersebut dibagi menjadi beberapa deskriptor, dengan indikator-indikator sebagai berikut:

a) Bertanya kepada guru dan teman tentang materi pelajaran

- Bertanya kepada guru terkait materi

- Mempertanyakan hasil penemuan kelompok lain

- Bertanya mengenai langkah percobaan

b) Antusias mencari jawaban

- Membaca materi pelajaran dari buku paket yang terkait dengan materi yang diajarkan,

- Menjawab pertanyaan yang dilontarkan guru

- Menjawab pertanyaan yang dilontarkan teman

c) Perhatian pada objek yang diamati

- Memperhatikan penjelasan guru mengenai objek yang diamati

- Menggunakan alat indera untuk mengamati objek atau peristiwa yang sedang diamati dengan sungguh-sungguh

- Mengamati objek atau peristiwa selama melakukan percobaan dengan sungguhsunguh

d) Antusias pada proses sains

- Melakukan kegiatan pengumpulan data dengan sungguhsungguh,

- Melakukan pemrosesan data dengan sungguh-sungguh

- Menunjukan minat pada hasil percobaan

e) Menunjukan keterampilan menyimak, berbicara, membaca dan menulis

- Berani berpendapat

- Mencatat penjelasan guru

- Mendengarkan penjelasan guru terkait materi dengan sungguh-sungguh 
Sikap rasa ingin tahu ini akan timbul jika objek yang dilihat dinilai menarik baginya. Akan tetapi, jika hal tersebut membosankan, maka orang akan cenderung mengabaikan dan tidak memiliki keinginan untuk mencari informasi yang mendalam mengenai hal tersebut. Sehingga upaya yang dapat dilakukan untuk mengembangkan rasa ingin tahu pada siswa, yaitu dengan memberikan kebebasan kepada siswa untuk bertanya dan mencari tahu hal ini bertujuan untuk melayani sikap rasa ingin tahu yang ada pada diri siswa tersebut. Sebagai seorang guru hanya berperan menjadi fasilitator yang hanya bertugas untuk memberitahu cara-cara kepada siswa dan siswa yang akan mencari jawaban dari pertanyaan yang mereka dapatkan.

Diperjelas oleh Yaumi (2016, 103) dalam bukunya yang mengatakan bahwa cara mengembangkan rasa ingin tahu dapat diuraikan sebagai berikut: (1) Jangan mengukur dan mengambil sesuatu dari nilai nominalnya. (2) Ajukan pertanyaan jika tidak mengetahui tentang sesuatu. (3) Hindari melakukan tindakan berpura-pura mengetahui, padahal sebenarnya belum memahaminya dengan baik. (4) Gunakan berbagai sumber untuk belajar; surat kabar, buku, jurnal, dan sumber-sumber dari internet. (5) Telaah latar belakang sesuatu, orang, dan kejadian atau peristiwa. (6) Gunakan kesempatan untuk berkomunikasi dengan orang dan bertanya tentang sesuatu yang mereka ketahui.

Suatu pembelajaran yang menarik dinilai sangat berpengaruh terhadap peningkatan rasa ingin tahu siswa. Hal ini di buktikan berdasarkan penelitian yang dilakukan oleh Silmi \& Kusmarni (2017) yang diketahui bahwa pada pembelajaran sejarah yang dilakukan dengan menerapkan media puzzle dalam proses pembelajaran pada Siklus I skor rata-ratanya mencapai 8,24, Siklus II skor rata-ratanya 8,31, Siklus III skor rata-ratanya adalah 10,7 dan pada Siklus IV memperoleh skor rata-rata 12,09. Pada setiap siklus, terlihat karakter rasa ingin tahu siswa cenderung mengalami kenaikan. Sehingga dapat disimpulkan bahwa penggunaan media puzzle ini dirasa cukup efektif untuk menumbuhkan karakter rasa ingin tahu siswa. 
Menurut Nasoetion dalam Irawinata $(2015,22)$ dalam Oktavioni (2017), terdapat 3 sumber rasa ingin tahu yaitu: (1) Kebutuhan: Rasa ingin tahu, muncul dari kesadaran kita akan kondisi masyarakat yang terdapat di sekitar ataupun sesuatu yang kita alami sehari hari. Rasa penasaran dan ingin tahu biasa kita alami jika ada suatu persoalan yang belum terselesaikan, yang misalnya karena masyarakat tidak mampu menanganinya. Ketidakmampuan ini biasanya di sebabkan karena pengetahuan dan sumber daya yang minim. Kondisi yang demikian dapat mendorong kita untuk mencari jawaban atau solusi persoalan tersebut. Disinilah rasa ingin tahu mulai bersaksi. Orang akan mencari cara untuk mengatasi persoalan tersebut. Cara mengatasi persoalan tersebut bisa di lakukan dengan membaca berbagai sumber yang berhubungan ataupun bertanya kepada orang yang berkapasitas, (2) Keanehan: Keanehan berasal dari kata aneh. Kata ini memiliki makna sesuatu yang di anggap tidak sesuai dengan apa yang umum di lihat maupun di rasakan karena berlawanan dengan kebiasaan atau aturan yang di sepakati. Rasa ingin tahu, bisa muncul kalau orang tersebut memandang ada suatu hal yang di anggap salah secara umum, namun tetap berlangsung di masyarakat. Misalnya, ada suatu perilaku masyarakat yang bertentangan dengan nilai nilai moral, hukum, ataupun agama. (3) Kebutuhan Vs Keanehan: Apa bedanya rasa ingin tahu karena kebutuhan dengan rasa ingin tahu karena keanehan? Kebutuhan, lebih berkaitan dengan ketidak mampuan masyarakat. Rasa ingin tahu siswa ini di awali dengan upaya mencari penjelasan, lalu berusaha memberi jalan keluar. Sedangkan rasa ingin tahu yang berasal dari keanehan berkaitan dengan cara kita memaknai fenomena yang ada di masyarakat. Secara singkat, rasa ingin tahu dari kebutuhan, dapat menghasilkan penelitian berupa produk yang dapat di manfaatkan. Yang dapat di sebut sebagai temuan. Sedangkan rasa ingin tahu dari keanehan, tujuannya adalah penggambaran dan penjelasan, yang kemudian di sebut sebagai pemahaman. 


\section{Pembelajaran Fisika}

Pembelajaran ini erat hubungannya dengan proses belajar dan mengajar, karena pembelajaran adalah proses interaksi yang terjadi pada peserta didik dengan pendidik dengan sumber belajar pada suatu lingungan belajar. Pembelajaran merupakan bantuan yang diberikan pendidik agar dapat terjadi proses perolehan ilmu dan pengetahuan, penguasaan kemahiran dan tabiat, serta pembentukan sikap dan kepercayaan pada peserta didik (Suardi 2018, 7). Pembelajaran juga merupakan proses perubahan yang terjadi dari hasil belajar yang mencakup semua aspek kehidupan guna untuk mencapai tujuan tertentu (Setiawan).

Proses pembelajaran pada satuan pendidikan diselenggarakan secara interaktif, inspiratif, menyenangkan, menantang, memotivasi peserta didik untuk berpartisipasi aktif, serta memberikan ruang yang cukup bagi prakarsa, kreativitas, dan kemandirian sesuai dengan bakat, minat, dan perkembangan fisik serta psikologis peserta didik. Untuk itu setiap satuan pendidikan melakukan perencanaan pembelajaran, pelaksanaan proses pembelajaran serta penilaian proses pembelajaran untuk meningkatkan efisiensi dan efektivitas ketercapaian kompetensi lulusan.

Sesuai dengan Standar Kompetensi Lulusan dan Standar Isi, maka prinsip pembelajaran kurikulum 2013 adalah a) dari peserta didik diberi tahu menuju peserta didik mencari tahu; b) dari guru sebagai satu-satunya sumber belajar menjadi belajar berbasis aneka sumber belajar; c) dari pendekatan tekstual menuju proses sebagai penguatan penggunaan pendekatan ilmiah; d) dari pembelajaran berbasis konten menuju pembelajaran berbasis kompetensi; e) dari pembelajaran parsial menuju pembelajaran terpadu; f) dari pembelajaran yang menekankan jawaban tunggal menuju pembelajaran dengan jawaban yang kebenarannya multi dimensi; g) dari pembelajaran verbalisme menuju keterampilan aplikatif; h) peningkatan dan keseimbangan antara keterampilan fisikal (hardskills) dan keterampilan mental (softskills); i) pembelajaran yang mengutamakan pem- 
budayaan dan pemberdayaan peserta didik sebagai pembelajar sepanjang hayat; j) pembelajaran yang menerapkan nilai-nilai dengan memberi keteladanan (ing ngarso sung tulodo), membangun kemauan (ing madyo mangun karso), dan mengembangkan kreativitas peserta didik dalam proses pembelajaran (tut wuri handayani); k) pembelajaran yang berlangsung di rumah, di sekolah, dan di masyarakat; l) pembelajaran yang menerapkan prinsip bahwa siapa saja adalah guru, siapa saja adalah siswa, dan di mana saja adalah kelas; m) Pemanfaatan teknologi informasi dan komunikasi untuk meningkatkan efisiensi dan efektivitas pembelajaran; dan n) pengakuan atas perbedaan individual dan latar belakang budaya peserta didik.

Pendidikan sains adalah salah satu aspek pendidikan yang menggunakan sains untukmencapaitujuan pendidikan, umumnya tujuan pendidikan nasional dan tujuan pendidikan sains khususnya, yaitu dengan meningkatkan pengetahuan terhadap dunia alamiah (Astalini dan Kurniawan 2019, 1). IPA berhubungan dengan cara mencari tahu tentang alam secara sistematis, sehingga IPA bukan hanya penguasaan kumpulan sistematis dan IPA bukan hanya penguasaan kumpulan pengetahuan yang berupa fakta-fakta, konsep-konsep atau prinsip-prinsip saja, tetapi juga merupakan suatu proses penemuan (Sri Sulistyorini 2007, 39).

Ilmu fisika adalah salah satu ilmu pembelajaran sains. Pembelajaran fisika berpacu pada konsep-konsep yang memerlukan pemahaman yang tinggi. Menurut Sunajem $(2012,103)$ Mata pelajaran fisika merupakan salah satu mata pelajaran yang cukup sulit bagi siswa dalam proses pembelajaran di kelas. Mata pelajaran fisika ini berisi masalah-masalah autentik yang ada di sekitar kehidupan siswa, miskonsepsi, konsep dan prinsip esensial dan strategis, contoh-contoh konseptual dan kontekstual, dan pertanyaan konseptual dan kontekstual yang memandu pemerolehan pemahaman konsep dan hasil belajar. 


\section{Pentingnya Rasa Ingin Tahu Siswa Terhadap Pembelajaran Fisika}

Pendidikan di Indonesia saat ini menekankan pada pendidikan karakter karena seseorang yang cerdas harus memiliki budi pekerti yang baik pula. Pendidikan karakter adalah pendidikan sepanjang hayat, sebagai proses kearah manusia yang sempurna. Oleh karena itu, pendidikan karakter memerlukan keteladanan dan sentuhan mulai sejak dini sampai dewasa (Supranoto 2015). Pendidikan karakter ini mengandung tiga unsur pokok menurut Marzuki (2013) dalam Supranoto (2015), yaitu mengetahui kebaikan (knowing the good), mencintai kebaikan (loving the good), dan melakukan kebaikan (doing the good).

Jika ditilik dari pengalaman sejarah bangsa, pendidikan karakter sesungguhnya bukan hal baru dalam tradisi pendidikan di Indonesia. Beberapa pendidik Indonesia modern seperti R.A. Kartini, Ki Hajar Dewantara, kemandirian nasional (National and character building) Soekarno, Hatta, Moh. Natsir dan lain sebagainya, telah mencoba menerapkan semangat pendidikan karakter sebagai pembentuk kepribadian dan identitas bangsa sesuai dengan konteks dan situasi yang mereka alami. Akan tetapi, seiring dengan perubahan zaman, agaknya menuntut adanya penanaman kembali nilai-nilai tersebut ke dalam sebuah wadah kegiatan pendidikan di setiap pembelajaran (Dalyono \& Lestariningsih 2017).

Pada kurikulum 2013 pemerintah menerapkan pendekatan saintifik sebagai pendekatan yang harus diterapkan pada saat pembelajaran berlangsung dan guru harus mengarahkan siswa agar melakukan 5M, yaitu: mengamati, menanya, mengumpulkan informasi, mengasosiasi, dan mengomunikasikan. Pembelajaran yang memungkinkan terjadinya pemberian jawaban yang bervariasi juga sangat disarankan. Karena itu, model-model pembelajaran yang memanfaatkan unsur-unsur dalam $5 \mathrm{M}$ dan open-ended, seperti Problem-Based Learning (PBL), Project-Based Learning (PjBL), dan Discovery Learning (DL) sangat disarankan untuk diterapkan dalam kurikulum 2013. 
Namun demikian, penerapan model-model pembelajaran tersebut menuntut ketekunan dan kesabaran, serta pemahaman yang baik tentang PBL, PjBL, maupun Discovery Learning. Kalau ingin menerapkan PBL, guru harus pandai memilih masalah otentik atau realistik yang membuat mereka tertarik dan tertantang untuk menyelesaikannya karena tidak semua masalah, bisa dijadikan dasar untuk penerapan PBL (As'ari 2014).

Selain tuntutan yang dijelaskan diatas, pada kurikulum 2013 pembelajaran harus bersifat student center. Oleh sebab itu terkadang satu guru tidak dapat mengimbangi banyaknya siswa di dalam kelas. Sementara, jika dalam satu pelajaran terdapat dua guru, maka pembelajaran akan kacau dan tidak terarah. Di beberapa tempat ditemukan siswa saling belajar bersama, berdiskusi, saling berbagi pengetahuan untuk mengimbangi hal tersebut. Kondisi inilah yang dianggap paling efisien dibandingkan harus menambah waktu belajar di bimbel. Sehingga siswa dituntut saling kerjasama agar pembelajaran lebih efektif dan efisien (Putri et al. 2018).

Sikap rasa ingin tahu yang timbul pada diri setiap siswa akan membeikan dampak yang baik pada proses pembelajaran diantaranya: (a) Suasana pembelajaran menjadi kondusif, (b) guru mudah untuk menerapkan kurikulum 2013 yang berpedoman pada pembelajaran student center, (c) meningkatkan kreatifitas siswa, dan (d) meningkatkan kemampuan siswa dalam berpikir kritis sehingga memicu peningkatan prestasi belajar pada diri siswa.

Menurut Taberner \& Siggins (2015, 4) dalam Raharja et.al. (2018) pada tahun 2011, Forbes mengakui rasa ingin tahu sebagai salah satu sikap dari semua pemimpin yang inovatif, mereka menggunakan kesuksesan Steve Jobs sebagai suatu contoh. Jobs tidak ingin tahu karena dia ingin menjadi sukses, tapi dia menjadi sukses karena dia sangat ingin tahu. Pernyataan tersebut di perjelas oleh Kashdan et.al. (2009) dalam Raharja et.al. (2018) bahwasanya saat seseorang memiliki rasa ingin tahu, mereka akan senantiasa untuk memberikan banyak perha- 
tian kepada suatu aktivitas, mencari informasi lebih dalam dan mendetail sehingga mereka akan cenderung untuk mengerjakan tugas sampai selesai. Sehingga dapat disimpulkan bahwa menimbulkan rasa ingin tahu siswa terhadap suatu materi dalam sebuah pembelajaran sangat penting.

\section{Deskripsi data}

Data diambil dari subjek penelitian (N) sebanyak 35 siswa dengan rata-rata (mean) sebesar 59.8, nilai tengah (Median) sebesar 61, standar desiasi sebesar 5.31258 dengan range 21 . Nilai minimum yang diperoleh pada penelitian dengan variabel rasa ingin tahu ini sebesar 48 , sedangkan nilai maximum yang diperoleh sebesar 69.

Hasil analisis angket menunjukkan bahwa sikap rasa ingin tahu siswa pada kelas X IPA di MAN 1 Batanghari dapat diklasifikasikan menjadi empat kelompok dengan rentang yang berbeda-beda. Pada rentang "18.0-31.5" dinilai sebagai sikap rasa ingin tahu yang tidak baik, rentang "31.6-45.1" dinilai sebagai sikap kurang baik, rentang "45.2-58.7" dinilai sebagai sikap baik, dan rentang "58.8-72.3" dinilai sikap sangat baik.

\section{Pembahasan}

Penelitian adalah upaya untuk mengembangkan ilmu pengetahuan dan upaya untuk mendapatkan temuan-temuan baru. Pengembangan penelitian dapat berupa pengembangan ilmu yang telah ada sebelumnya. Temuan-temuan baru tersebut dapat berupa pembuktian atau benar-benar menemukan pengetahuan-pengetahuan baru (Hanafi 2017, 130). Menurut Darmawan (2014, 9-10), penelitian yang dilakukan dalam konteks atau bidang apa pun akan selalu memiliki kegunaan tertentu. Dimana peran penelitian yaitu: (a) Pemecahan Masalah, (b) Meningkatkan kemampuan untuk meninterpretasikan fenomena-fenomena dari suatu masalah, (b) Memberikan jawaban atas pertanyaan dalam bidang yang diajukan, (c) Meningkatkan kemampuan untuk menjelaskan atau menggambarakan fenomena-fenomena 
dari masalah tersebut, dan (d) Mendapatkan pengetahuan atau ilmu baru.

Penelitian yang telah dilakukan dengan judul Identifikasi Sikap Rasa Ingin Tahu Siswa Terhadap Pembelajaran Fisika di MAN 1 Batanghari ini memperoleh hasil bahwasanya terdapat 9 siswa yang memperoleh nilai baik dengan persentase $25.7 \%$ dan 26 siswa yang memperoleh nilai sangat baik dengan persentase 74.3\%. Hal ini menunjukkan bahwa sikap rasa ingin tahu yang ada pada siswa kelas X IPA di MAN 1 Batanghari tergolong kuat, dibuktikan juga dengan adanya pertanyaan-pertanyaan yang diajukan siswa pada saat observasi. Pada prinsipnya mempelajari fisika adalah sebagai cara mencari tahu dan cara melakukan yang dapat membantu siswa untuk memahami fenomena-fenomena alam sekitar secara lebih mendalam, untuk itu dibutuhkan pendidikan fisika karena dapat menekankan pada pemberian pengalaman secara langsung. Oleh sebab itu, diperlukan rasa ingin tahu yang tinggi pada diri siswa dalam peroses pembelajaran. Rasa ingin tahu juga merupakan keinginan untuk menyelidiki dan mencari pemahaman terhadap rahasia alam (Samani et.al. 2012). Rasa ingin tahu senantiasa akan memotivasi diri untuk terus mencari dan mengetahui hal-hal yang baru sehingga akan memperbanyak ilmu pengetahuan dan pengalaman dalam kegiatan belajar.

Berdasarkan hasil penelitian yang diperolah, siswa kelas X IPA di MAN 1 Batanghari lebih dari setengah tergolong sangat baik. Artinya, siswa kelas X IPA di MAN 1 Batanghari memiliki sikap rasa ingin tahu yang tinggi. Untuk itu perlu dilakukan penelitian lebih lanjut untuk membuktikan apakah benar dengan rasa ingin tahu yang tinggi tersebut dapat meningkatkan pengetahuan dan pola berpikir kritis pada siswa.

\section{E. Kesimpulan}

Proses Pembelajaran pada satuan pendidikan diselenggarakan secara interaktif, inspiratif, menyenangkan, menantang, memotivasi peserta didik untuk berpartisipasi aktif, 
serta memberikan ruang yang cukup bagi prakarsa, kreativitas, dan kemandirian sesuai dengan bakat, minat, dan perkembangan fisik serta psikologis peserta didik. Ketika seseorang memiliki rasa ingin tahu, mereka akan senantiasa untuk memberikan banyak perhatian kepada suatu aktivitas, mencari informasi lebih dalam dan mendetail sehingga mereka akan cenderung untuk mengerjakan tugas sampai selesai. Dapat disimpulkan bahwa menimbulkan rasa ingin tahu siswa terhadap suatu materi dalam sebuah pembelajaran sangat penting. Oleh karena itu, dibutuhkan peran guru sebagai fasilitator dan motivator yang cerdas dalam menghadapi situasi pembelajaran di kelas.

\section{BIBLIOGRAPHY}

As'ari, A. R. 2014. "Mengupayakan Pembelajaran yang Sesuai Tuntutan Kurikulum 2013.” Conference Paper. https://10.13140/2.1.1389.2644

Dalyono, B. \& E. D. Lestariningsih. 2017. "Implementasi Penguatan Pendidikan Karakter di Sekolah." Bangun Rekaprima 2(3).

Daryanto dan Suryati Darmiatun. 2013. Implementasi Pendidikan Karakter Di Sekolah Dasar. Yogyakarta: Gava media.

Fauzi et.al. 2017. "Penguatan Karakter Rasa Ingin Tahu dan Peduli

Sosial Melalui Discovery Learning." Jurnal Teori dan Praksis Pembelajaran IPS 2(2): 27-36.

Hanafi. 2017. "Konsep Penelitian R\&D Dalam Bidang Pendidikan."

Saintifika Islamica 2(4), 129-150, https://ejournal.undiksha.ac.id/ index.php/janapati/article/view/9825.

Kemendiknas. 2010. Pengembangan Pendidikan Budaya dan Karakter Bangsa Pedoman Sekolah. Jakarta: Pusat Kurikulum. Kurniawan, Samsul. 2013. Pendidikan Karakter: Konsepsi \& Implementasinya Secara Terpadu di Lingkungan Keluarga, Sekolah, Perguruan Tinggi, dan Masyarakat. Yogyakarta: ArRuzz Media.

Oktavioni, W. 2017. Meningkatkan Rasa Ingin Tahu Siswa pada Pembelajaran IPA Melalui Model Dscovery Learning di Kelas 
V SD Negeri 186/1 Sridadi. Skripsi. Universitas Jambi.

Priyono, E. D. 2018. Analisis Rasa Ingin Tahu Siswa Pada Mata Pelajaran IPA Dikelas VIII MTs An-Nuriyah Tanjung Pasir. Skripsi. Universitas Muhammadiyah Pontianak.

Putri, N.A. 2011. "Penanaman Nilai-nilai Pendidikan Karakter melalui Mata pelajaran Sosiologi." Komunitas 3(2): 201-215, http://journal. unnes.ac.id/nju/index.php/komunitas/ article/dow nload/2317/2370.

Raharja et.al. 2018. "Mengukuur Rasa Ingin Tahu Siswa (Measuring Students' Curiosity)." A Journal of Language, Literature, Culture, and Education POLYGLOT 2(14).

Silmi, M \& Y. Kusmarni. 2017. "Menumbuhkan Karakter Rasa Ingin Tahu Siswa Dalam Pembelajaran Sejarah Melalui Media Puzzle." Factum 2(6).

Suardi. M. 2018. Belajar \& Pembelajaran. Yogyakarta: Deepublish.

Yaumi, M. 2016. Pendidikan Karakter: Landasan, Piar, dan Implementasi. Jakarta: Prenadamedia Group. 